\title{
PEMBERIAN REWARD AND PUNISHMENT KEPADA ANAK MENURUT PERSPEKTIF PENDIDIKAN ISLAM
}

\author{
Nur Husna \\ Universitas Lambung Mangkurat, Banjarmasin \\ nur.husna@ulm.ac.id
}

\begin{abstract}
In the world of education, rewards are given when a child has succeeded in reaching a certain stage of development, a good achievement, or the achievement of a target. Conversely, punishment is usually carried out when certain targets are not achieved, or there is a child's behavior that is not in accordance with the norms believed by the school. In Islam there are terms basyir (happy news) and nadzir (threatening news) which are analogous to rewards and punishments. The purpose of this study was to determine the application of reward and punishment in Islamic education. The method used in this research is descriptive-analytical with qualitative, inductive, psychological, and educational approaches. The data collection technique in this study uses a library research where all research data refers to the literature related to the object of research. The findings of the authors of the analysis are that Reward and Punishment in Islamic education cannot be separated from the concept of the goal of Islamic education, which is to create righteous human beings like the Prophet. Its application is also inseparable from imitating the Prophet's attitudes, and his ways of educating Muslims both in the Al-Qur'an and the Sunnah. Giving rewards and punishments must also be considered so that they are not mistaken, right on target, and have a positive impact on children's responses.
\end{abstract}

Keywords: Children, Islamic Education, Punishment, Reward

\section{Abstrak}

Dalam dunia pendidikan, reward diberikan ketika seorang anak telah berhasil mencapai sebuah tahap perkembangan tertentu, achievement yang bagus, atau tercapainya sebuah target. Sebaliknya, punishment biasanya dilakukan ketika apa yang menjadi target-target tertentu tidak tercapai, atau ada perilaku anak yang tidak sesuai dengan norma-norma yang diyakini oleh sekolah tersebut. Dalam Islam ada istilah basyir (berita gembira) dan nadzir (berita ancaman) yang dianalogikan dengan penghargaan dan hukuman. Tujuan dari penelitian ini adalah untuk mengetahui penerapan reward and punishment dalam pendidikan Islam. Metode yang digunakan dalam penelitian ini adalah deskriptif-analitis dengan pendekatan kualitatif induktif, psikologis, dan ilmu pendidikan. Adapun teknik pengumpulan data dalam penelitian ini menggunakan kepustakaan (library research) dimana seluruh data penelitian merujuk pada literatur yang berkaitan dengan objek penelitian . Hasil temuan yang penulis analisis adalah bahwa Reward and Punishment dalam pendidikan Islam tidak bisa dipisahkan dari konsep tujuan pendidikan Islam itu sendiri, yaitu meciptakan manusia insan kamil yang bertakwa seperti Rasulullah. Penerapannya pun tidak lepas dari peneladanan kepada sikap-sikap Nabi, dan cara-cara beliau dalam mendidik umat Islam baik yang terdapat di Al-Qur'an 
ataupun Sunnah. Pemberian reward dan punishment juga harus diperhatikan agar tidak salah kaprah, mengena, dan memiliki dampak positif terhadap respon anak.

Kata kunci: Anak, Pendidikan Islam, Punishment, Reward

\section{PENDAHULUAN}

Dalam proses pertumbuhan dan perkembangannya, anak harus dipandang sebagai hamba Tuhan yang paling mulia dengan kemampuan dan bakat yang bisa berkembang secara intensif atau dialektis (saling mempengaruhi) antara kemampuan dasarnya dan pengaruh Pendidikan (Arifin, 2009). Sehingga merupakan suatu yang lumrah jika menjumpai anak dengan karakter yang beragam dikarenakan kecerdasan atau pengaruh pendidikannya tersebut. Namun ada anak yang mudah dibina dan ada yang sulit dibina, sebagian giat belajar dan sebagian lain sangat malas belajar, sebagian mereka belajar untuk maju dan sebagian lain belajar hanya untuk terhindar dari hukuman.

Sifat-sifat buruk yang timbul dalam diri anak bukanlah lahir dari fitrah mereka. Sifat-sifat tersebut timbul karena kurangnya peringatan sejak dini dari orang tua dan para pendidik. Maka merupakan kesalahan besar apabila orang tua dan para pendidik menyepelekan kesalahan-kesalahan kecil yang dilakukan anak (Purwanto, 1995). Dalam konteks pendidikan dikenal konsep reward (hadiah) dan punishment (hukuman). Khalil A. Khavari seperti yang dikutip oleh Agung Prihantoro (2006) mengatakan bahwa:

Hadiah dan hukuman mulai membentuk kita sejak kita lahir. Bayi yang lapar menangis, dan kemudian sang ibu biasanya menyusuinya. Bayi yang merasa bosan juga menangis, lalu orang tuanya menggendong dan bermain-main dengannya. Bayi pun belajar dan tahu bahwa tangisannya menerbitkan konsekuensi-konsekuensi yang menggembirakan, sehingga dia akan menggunakan tangisan sebagai senjata selama itu masih efektif. Setelah mengetahui bahasa verbal untuk mengungkapkan kebutuhan-kebutuhannya, anak akan memakai kata-kata, bukan tangisan lagi.

Lebih lanjut Khalil A. Khavari (2006) mengatakan bahwa setelah manusia bertambah dewasa, kebutuhan dan keinginannya pun bertambah dengan cepat, dan cara-cara terdahulu untuk memenuhi mereka, yakni dengan menangis atau meminta orang tua melalui kata-kata, menjadi tak sesuai atau tak efektif lagi. Lantas, dia pun mulai menggunakan cara-cara lain yang lebih tepat untuk meraih hasil-hasil yang membahagiakannya. 
Reward merupakan suatu bentuk teori reward positive yang bersumber dari aliran Behavioristik yang dikemukakan oleh Thorndike, Watson, Ivan Pavlov, Skinner dan kawan-kawan dengan teori S-R (Stimulus-Respon). Reward adalah suatu bentuk perlakuan positif subjek (Mulyasa, 2007). Reward atau penghargaan merupakan respon terhadap suatu tingkah laku yang mendapat peningkatan yang kemungkinan terulang kembalinya tingkah laku tersebut.

Sedangkan teori tentang hukuman (punishment) diantaranya yaitu teori hukum alam yang dikemukakan oleh penganjur pendidikan alam, J.J Rousseau. Rousseau tidak menghendaki hukuman yang dibuat-buat. Biarkan alam sendiri yang menghukumnya. Yang dimaksud di sini ialah bahwa hukuman itu hendaknya merupakan akibat yang sewajarnya dari suatu perbuatan. Hukuman harus merupakan sesuatu yang natur menurut hukumhukum alam, sesuatu akibat logis yang tidak dibuat-buat (Indrakusuma, 1973).

Dapat disimpulkan bahwa reward and punishment merupakan suatu bentuk teori yang berasal dari aliran psikologi, kemudian dikembangkan dalam pendidikan sebagai alat pendidikan untuk memotivasi peserta didik dalam proses belajar mengajar. John W. Santrock (2005) mengkategorikannya sebagai motivasi ekstrinsik yaitu terdapat dalam bukunya CHILDREN yang berbunyi "extrinsic motivation is external incentives such as reward and punishment" (motivasi ekstrinsik adalah insentif eksternal seperti hadiah dan pujian).

Disiplin diri merupakan tujuan sekaligus proses pendidikan kemandirian. Sedangkan prinsip kasih sayang yang merupakan ekspresi dari bashir dan reward memang sudah seharusnya diterapkan dalam aktivitas sehari-hari proses belajar mengajar, terlebih-lebih dewasa ini aspek materialisme sering mengalahkan prinsip-prinsip keagamaan. Ternyata Walisongo yang pengaruh pendidikan mereka terlembagakan dewasa ini dalam bentuk pesantren, juga menekankan pendidikan kasih sayang yang menjadi tujuan pendidikan Islam yaitu terbentuknya insan kamil yang kembali pada pribadi Rasulullah yang penyayang, penuh kasih sayang dan berakhlak mulia.

Banyak kontribusi para tokoh muslim dalam bidang pendidikan Islam, seperti konsep pendidikan Ibn Maskawih yang tidak dapat dilepaskan dari konsepnya tentang manusia dan akhlak. Durrotul Mufidah (2008) mengatakan bahwa:

Ibn Maskawih dalam membangun konsep pendidikan lebih bertumpu atau lebih cenderung pada pendidikan akhlak. Hal ini terlihat jelas bahwa dasar pemikiran Ibn Maskawaih tersebut memang benar-benar didasarkan pada 
konsep dia tentang pendidikan akhlak. Maka dari itu pendidikan yang dibangun adalah pendidikan akhlak, yang meliputi: tujuan pendidikan akhlak, materi pendidikan akhlak, pendidikan dan anak didik, lingkungan pendidikan, dan metodologi pendidikan.

Namun Abuddin Nata (2001) berpendapat bahwa kelemahan konsep pendidikan Ibn Maskawih terlihat dalam merincikan konsep pendidikan secara kurang detail karena beliau hanya memaparkan konsep pendidikan yang wajib bagi manusia dan bukan mengkaji dan menguraikan persoalan dan hal-hal yang lainnya.

Pemikiran tokoh muslim lainnya juga berkontribusi bagi pendidikan Islam, terutama mengenai penerapan hadiah dan hukuman sebagai alat untuk mendidik anak. Ibnu Jama'ah berpendapat bahwa pemberian hadiah lebih kuat dan lebih berpengaruh terhadap pendidikan anak daripada pemberian hukuman. Ibnu Jama'ah lebih memprioritaskan penguatan dengan penerimaan, anggapan baik, pujian, dan sanjungan. Guru perlu menjelaskan kepada siswanya bahwa pujian itu disebabkan oleh upaya dan keunggulan, sehingga siswa pun memahaminya. Hal ini bersinggungan dengan sisi penting tabiat manusia, yaitu apabila manusia memperoleh dorongan, maka itu akan memacunya untuk maju dan meningkatkan diri. Jika menemukan celaan dan cercaan, dia akan mundur dan semangatnya berkurang (Budaiwi, 2002).

Abdurrahman Mas'ud dalam jurnalnya yang berjudul "Reward and Punishment dalam Pendidikan Islam" lebih memprioritaskan reward daripada punishment. Menurut beliau, punishment (khususnya hukuman fisik) tidak membawa dampak positif (sebaliknya membawa kenangan horor bagi siswa). Sedangkan penulis dalam penelitian ini berpandangan bahwa sebenarnya bukan hanya reward yang dapat berpengaruh positif terhadap diri anak didik, tetapi punishment pun dapat menjadi acuan positif dalam mendidik anak. Dengan catatan yaitu pendidik harus mengetahui syaratsyarat dan metode pemberian reward and punishment yang baik.

Oleh sebab itu, terlepas dari kelebihan dan kekurangan dari keduanya, maka penulis menyimpulkan bahwa reward and punishment bisa menjadi alternatif alat pendidikan yang dapat memajukan pendidikan, terutama pendidikan Islam, jika diberikan secara seimbang dan sesuai porsinya. Jika reward merupakan bentuk reinforcement yang positif, maka punishment sebagai bentuk reinforcement yang negatif, tetapi kalau diberikan secara tepat dan bijak bisa menjadi alat motivasi. Tujuan dari metode ini adalah menimbulkan rasa tidak senang pada seseorang supaya mereka jangan membuat sesuatu yang jahat. Jadi, hukuman yang dilakukan mesti bersifat pedagogies, yaitu untuk memperbaiki dan mendidik ke arah yang lebih baik. 


\section{METODE}

Metode Penelitian ini termasuk penelitian dasar/fundamental dan konseptual. Penelitian dasar/fundamental adalah penelitian yang bertujuan menemukan pengetahuan baru yang sebelumnya belum pernah diketahui (Sugiyono, 2009). Disebut pencarian pengetahuan untuk pengetahuan karena ia masih menjadi tambahan pada ilmu yang telah ada.

Adapun sumber data didapat melalui kepustakaan (Library Research) dimana seluruh data penelitian merujuk pada literatur yang berkaitan dengan objek penelitian (Suryabrata, 1989). Melalui penelitian kepustakaan, penulis mencoba menelaah buku-buku untuk mendapatkan informasi yang berkaitan dengan masalah yang dibahas terutama untuk mendeskripsikan kajian teoritis yang telah ditetapkan.

Berdasarkan isinya, bahan pustaka atau sumber data dibagi menjadi dua: data primer dan data sekunder. Data primer adalah gudang atau tempat penyimpan yang orisinil. Dengan kata lain, data primer adalah segala sumber yang direkam individu yang hadir pada waktu kejadian berlangsung (Arikunto, 2000). Sedangkan data sekunder adalah catatan tentang adanya suatu peristiwa, ataupun catatan-catatan yang jaraknya telah jauh dari sumber orisinilnya (Nazir, 2003).

Maka dalam data primer, penulis mengkaji data kepustakaan tentang reward and punishment dalam pendidikan Islam, berupa buku-buku yang terkait dengan topik pembahasan. Adapun data sekunder adalah data-data pendukung yang bersumber dari komentar atau karya tulis orang lain.

Penelitian ini akan mengupas tentang konsep dan filosofis Reward and Punishment dalam Pendidikan Islam, maka metode yang digunakan dalam penelitian ini adalah deskriptif-analitis dengan pendekatan kualitatif induktif, psikologis, dan ilmu pendidikan.

Pendekatan deskriptif bertujuan memberikan gambaran tentang suatu masyarakat atau kelompok orang tertentu, atau gambaran tentang suatu gejala, hubungan antara dua gejala atau lebih (Soehartono, 2002). Dalam kata lain, deskriptif adalah menggambarkan suatu hal dengan apa adanya (Partanto dan Al-Barry, 1994). Sedangkan pendekatan analitis berarti uraian (Partanto dan Al-Barry, 1994). Yakni pembahasan yang memaparkan data yang telah tersusun dengan melakukan kajian dan analisa terhadap data-data tersebut. Sedangkan Ibnu Hajar (1999) secara lebih rinci menjelaskan bahwa deskriptif-analitis adalah suatu metode penelitian yang berusaha untuk mendeskripsikan fenomena yang diselidiki dengan cara melukiskan dan mengklasifikasikan fakta atau karakteristik fenomena tersebut secara faktual dan cermat. Hal ini bisa mengenai kondisi, pendapat, proses, akibat atau efek yang terjadi atau kecenderungan baik berkenaan dengan masa kini atau juga memperhitungkan peristiwa masa lampau dan pengaruhnya terhadap 
kondisi masa kini. Penelitian ini digunakan untuk menjawab pertanyaan tentang apa atau bagaimana keadaan sesuatu (fenomena, kejadian tersebut) dan melaporkan sebagaimana adanya. Karena sifatnya alamiah, deskriptif tidak dimaksudkan untuk menguji teori hingga tidak ada manipulasi perlakuan terhadap subjek maupun variabel.

\section{HASIL DAN PEMBAHASAN}

\section{A. Reward and Punishment}

Menurut Bahasa, reward berasal dari bahasa Inggris yang berarti something given in return for work or service or for bringing back stolen property (Martin, 2003). Sedangkan dalam bahasa Indonesia sering diartikan sebagai ganjaran, hadiah, upah, dan penghargaan (Echols dan Sadily, 2003). Ada banyak ahli yang mengemukakan pendapatnya masing-masing tentang pengertian reward. Beberapa diantaranya menyimpulkan sebagai alat pendidikan refresif.

M. Hafi Anshari (1993) mengemukakan bahwa reward adalah alat pendidikan refresif yang bersifat menyenangkan dan membangkitkan atau mendorong anak untuk berbuat sesuatu yang lebih baik, terutama kepada anak yang malas. Reward diberikan kepada anak yang mempunyai prestasiprestasi dalam pendidikan, memiliki kerajinan dan tingkah laku yang baik sehingga dapat dijadikan contoh teladan bagi kawan-kawannya.

Elizabeth Bergner Hurlock (1990) memposisikan reward sebagai salah satu pilar dari disiplin, menurutnya reward berarti tiap bentuk penghargaan untuk suatu hasil yang baik, penghargaan tidak perlu berbentuk materi, tetapi berupa kata-kata pujian, senyuman atau tepukan di punggung. Pendapat ini disetujui oleh Thomson, menurutnya penguatan positif, reward, dapat diberikan dengan dua model. Pertama, pemberian hadiah kasih berupa memuji, menepuk punggung, memeluk atau menyentuh dengan penuh kasih. Kedua, pemberian hadiah materi semisal pergi ke restoran untuk makan es krim, memberi permen atau coklat, menambah waktu untuk menonton televisi, mengizinkan menonton acara khusus atau membawanya berpiknik (Setiawani, 2000).

Reward merupakan suatu bentuk teori reward positive yang bersumber dari aliran Behavioristik yang dikemukakan oleh Thorndike, Watson, Ivan Pavlov, Skinner dan kawan-kawan dengan teori S-R (Stimulus-Respon) (Mulyasa, 2007). Behavioristik adalah teori belajar yang lebih menekankan pada tingkah laku manusia. Teori ini memandang individu sebagai makhluk reaktif yang memberi respon terhadap lingkungan. Kini kata Behavioristik biasanya digunakan untuk melukiskan isi jumlah teori yang saling berhubungan di bidang psikologi, sosiologi, dan ilmu-ilmu tentang tingkah laku (Shaleh, 2008). 
Dengan demikian dapat disimpulkan bahwa pada dasarnya reward digunakan dalam arti luas dan fleksibel, tidak terbatas pada sesuatu pemberian yang bersifat materi semata, akan tetapi inti darinya menimbulkan efek rasa senang, kepuasan batin, dan simpatik atas apa yang telah diperbuat. Sehingga timbul karenanya sesuatu yang bersifat positif. Reward juga diberikan dengan harapan ada peningkatan motivasi terhadap prestasi dan kebaikan yang ditampilkannya, sehingga yang diberikan reward selalu berusaha untuk meningkatkan kemauan untuk tampil gemilang dengan prestasi yang diharapkan

Kemudian, menurut Manser H. Martin (2003) dalam Oxford learner's Pocket Dictionary, punishment berasal dari kata punish yaitu make somebody suffer because they have broken the law or done something wrong, atau dalam artian hukuman adalah 'membuat seseorang menderita karena mereka telah melanggar aturan hukum atau telah melakukan suatu kesalahan'. Sedangkan punishment dalam bahasa keseharian sering diartikan dengan pemberian sanksi atau hukuman. Elizabeth Bergner Hurlock yang dikutip oleh Meitasari Tjandrasa (1990) mendefinisikan punishment yaitu means to impose a penalty on a person for a fault offense or violation or retaliation. Hukuman ialah menjatuhkan suatu siksa pada seseorang karena suatu pelanggaran atau kesalahan sebagai ganjaran atau balasannya.

Punishment disejajarkan dengan konsep disiplin, di samping punishment juga merupakan salah satu pilar dari disiplin sendiri. Menurut konsep ini, disiplin digunakan hanya bila terjadi suatu pelanggaran peraturan dan perintah. Dengan demikian disiplin terkait dengan peraturan dan hukuman akibat melanggar peraturan tersebut. Tujuan disiplin sendiri adalah untuk membentuk tingkah laku sehingga perilaku tersebut sesuai dengan peraturan yang ditetapkan oleh budaya dimana individu itu berada (Hurlock, 1990). Karena punishment pengaruhnya lebih bersifat tegas dan ada unsur pencegahan terhadap perilaku yang melanggar. Disini juga terkandung pengertian bahwa disiplin merupakan cara untuk mengajari anak bertingkah laku menuju kehidupan yang lebih baik, kebaikan pribadi dan sosial.

M. Hafi Anshari (1993) mengkategorikan hukuman ke dalam tiga batasan. Pertama perubahan rasa sakit atau tidak suka terhadap subjek karena kegagalan perbuatan untuk menyesuaikan diri terhadap batasan dalam eksperimen, kedua suatu rangsangan dengan valensi negatif atau rangsangan yang sanggup untuk mengubah rasa sakit atau ketidaksenangan, dan ketiga gangguan terhadap periode pengurangan pada orang yang resmi bersalah, lawannya reward.

Dari beberapa pendapat di atas dapat disimpulkan bahwa punishment diberikan dengan tujuan ada kesadaran untuk menghentikan prilaku negatif 
yang diperbuat, dan menumbuhkan kesadaran bahwa perbuatan itu tidak mendatangkan kebaikan dan kesenangan sejati. Dengan adanya kemampuan memperhitungkan setiap resiko yang akan dihadapi jika melakukan perbuatan yang melanggar, seseorang dapat memilih perbuatan lain yang lebih baik dan tidak melanggar. Sehingga hal ini menimbulkan kesadaran dalam diri atas bantuan dari resiko yang ditimbulkan oleh punishment.

\section{B. Bentuk Reward and Punishment dalam Pendidikan Islam}

Pendidikan Islam adalah upaya membimbing, mengarahkan, dan membina peserta didik yang dilakukan secara sadar dan terencana agar terbina suatu kepribadian yang utama sesuai dengan nilai-nilai ajaran Islam. Tujuan ini dapat dijabarkan pada tingkat yang lebih rendah lagi, menjadi tujuan yang bercorak nasional, institusional, terminal, klasikan, perbidang studi, berpokok ajaran, sampai dengan setiap kali melaksanakan kegiatan belajar mengajar (Nata, 2000).

Berbicara tentang reward and punishment dalam pendidikan Islam, maka dasarnya pun akan sama dengan pendidikan Islam, yaitu yang utama adalah bersumber dari Al-Qur'an dan Hadis. Reward di dalam Al-Quran biasanya disebutkan dalam berbagai bentuk uslub, di antaranya ada yang mempergunakan lafadz 'ajr ( أجر ) dan tsawab (ثواب). Abdurrahman Mas'ud mengatakan bahwa manusia yang bertakwa selalu menjadi salah satu kunci dalam rumusan tujuan pendidikan Islam. Karena pada dasarnya pendidikan adalah proses menuju kesempurnaan individu, maka memasukkan kata kamil sesungguhnya juga tidak kalah penting. Nabi Muhammad SAW sebagai insan al-kamil dan sekaligus sebagai model paripurna telah disepakati dalam dunia Islam.

Dengan demikian sikap-sikap Nabi, dan cara-cara beliau dalam mendidik umat Islam merupakan rujukan penting setelah Al-Qur'an. Nabi Muhammad SAW adalah insan al-kamil, sekaligus guru terbaik, Beliau tidak hanya mengajar, mendidik, tapi juga menunjukkan jalan. Kehidupannya demikian memikat dan memberikan inspirasi kepada manusia untuk mentransfer nilai-nilai luhur darinya hingga menjadi manusia-manusia baru.

Sabda Nabi yang berkaitan dengan punishment yaitu:

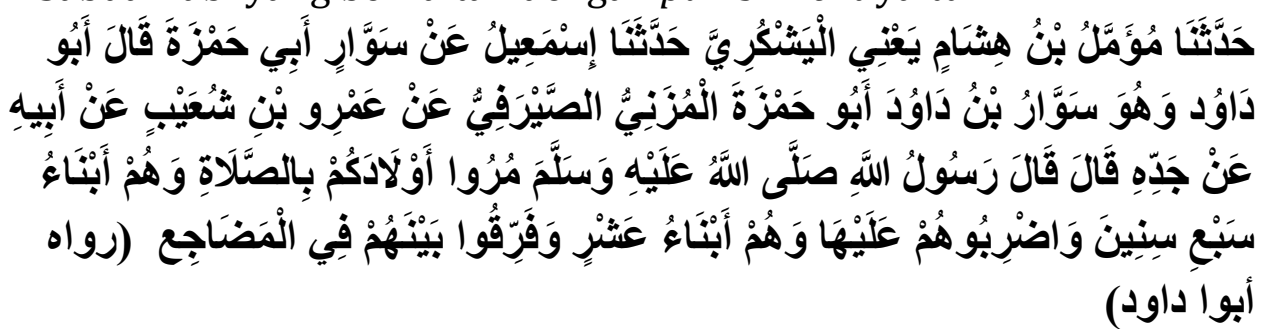

Artinya: "Telah menceritakan kepada kami Mu`ammal bin Hisyam AlYasykuri telah menceritakan kepada kami Isma'il dari Sawwar Abu Hamzah 
berkata Abu Dawud; Dia adalah Sawwar bin Dawud Abu Hamzah Al-Muzani Ash-Shairafi dari Amru bin Syu'aib dari Ayahnya dari Kakeknya dia berkata; Rasulullah shallallahu 'alaihi wasallam bersabda: Perintahkanlah anakanak kalian untuk melaksanakan shalat apabila sudah mencapai umur tujuh tahun, dan apabila sudah mencapai umur sepuluh tahun maka pukullah dia apabila tidak melaksanakannya, dan pisahkanlah mereka dalam tempat tidurnya." (HR. Abu Dawud)

Abu Thayyib Muhammad Syamsul Haq mengartikan makna ( واضربو ) dalam hadits tersebut adalah memberikan hukuman pukulan secara fisik, karena anak meninggalkan shalat. Di samping itu, pukulan yang diberikan harus mengenai badannya dan tidak boleh mengenai wajahnya. Sebab, pukulan tersebut harus diberikan kepada anak ketika sudah berumur 10 tahun, karena pada usia 10 tahun ke atas anak sudah dianggap mempunyai tanggung jawab (baligh). Sehingga dapat disimpulkan bahwa hadis di atas menjelaskan bahwa siapapun yang mengerjakan perbuatan dosa atau melakukan kesalahan, maka akan mendapatkan hukuman sesuai dengan tingkat kesalahan yang diperbuatnya.

Reward dapat diberikan dalam bentuk pemberian harapan akan kenikmatan yang akan diperoleh apabila suatu kebaikan ia lakukan (Najati, 2005). Muhammad Usman Najati menukil ayat Al-Qur'an surat Al-Baqarah ayat 82. Ayat tersebut dapat dipahami bahwa Allah memberikan janji kepada orang yang beriman dan beramal shaleh akan masuk ke dalam surga dan akan kekal di dalamnya selama-lamanya. Dan Allah tidak hanya memberikan janji akhirat, akan tetapi juga akan memberikan kebaikan kepada orang-orang mukmin di dunia.

Bentuk reward dalam pendidikan Islam diantaranya adalah sebagai berikut (Arif, 2002):

a. Pujian yang indah, agar anak lebih semangat dalam beramal.

b. Imbalan materi atau hadiah, karena pada umumnya anak-anak sangat termotivasi dalam melakukan sesuatu yang akan mendatangkan hadiah.

c. Do'a, misalnya "semoga Allah SWT menambah kebaikan padamu".

d. Tanda penghargaan, hal ini sekaligus menjadi kenang-kenangan bagi anak-anak dari kebaikan yang ia lakukan.

e. Memberikan wasiat tentang kebaikan anak, sehingga ia merasa bahwa kebaikan yang ia lakukan dihargai orang.

Pendapat lain mengatakan bahwa bentu reward dapat berupa (Mursi, 2004):

a. Menulis namanya dalam album kenangan, bagi sebagian anak cara seperti ini lebih berharga daripada pemberian hadiah dalam bentuk lain.

b. Tidak menjatuhkan hukuman kepada anak karena kesalahan temannya bersalah.

c. Menambah uang jajannya. 
d. Mengkhususkan sapaan kepadanya.

e. Membebaskankannya dari berbagi tugas dan kewajiban.

f. Memilih dia terlebih dahulu, misalnya dalam kegiatan wisata atau permainan, anda bisa memulai pemilihan dari orang yang ingin anda buka hatinya dan rebut simpatinya.

Sedangkan bentuk-bentuk punishment diantaranya adalah:

a. Teguran langsung, dimana teguran langsung disampaikan saat anak melakukan kesalahan. hal seperti ini pernah dilakukan oleh Rasulullah SAW, dari Umar bin Abi Salamah berkata, dulu aku menjadi pembantu dirumah Rasul SAW, ketika makan biasanya aku mengulurkan tanganku keberbagai penjuru melihat itu Rasul SAW berkata, " hai ghulam, bacalah basmalah, makanlah dengan tangan kananmu dan makanlah apa yang ada didekatmu". Dari hadis ini dapat dipahami bahwa Rasulullah Saw langsung menegur Umar bin Abi Salmah, ketika membuat kesalahan (Al-Amir, 1990).

b. Sindiran, sindiran dimaksudkan untuk menjaga wibawa anak-anak di hadapan teman-temannya, sehingga ia tidak rendah diri. Rasul SAW bersabda, "apa keinginanmu dengan mengatakan begini dan begitu? Sesungguhnya aku shalat, dan tidur, aku berpuasa dan berbuka (AlAmir, 1990).

c. Membuat anak takut kepada Allah dan ancaman azab-Nya, Sebagaimana hadis Rasulullah SAW: "Wahai Fatimah, mintalah dariku apa yang kamu inginkan dari hartaku, karena aku tidak kuasa menolak siksa Allah SWT dari dirimu." (HR. Bukhari)(Ali, 1998)

d. Menghukum dengan cara menjauhi dan tidak berinteraksi dengan anak. Hal ini sesuai dengan hadis Nabi berikut: ...Rasulullah SWA melarang bermain al-khafdzu, sebab al-khafdzu tidak tidak bisa membunuh binatang buruan, tidak bisa melukai musuh, malahan bisa melukai mata dan bisa menyebabkan gigi pecah, namun ia mengulangi lagi hal tersebut, lalu Ibnu Mughaffal berkata kepadanya " aku telah bilang kepadamu bahwa Rasulullah SAW membenci dan melarang hal tersebut, namun kamu tetap mengulanginya lagi, aku tidak akan berbicara denganmu lagi." (H.R. Thabrani) (Ibrahim)

e. Hukuman yang mendidik dan bermanfaat, seperti: memberikan nasehat dan pengarahan, mengerutkan muka, menghentikan kenakalannya, menyindir, mendiamkan, teguran, duduk dengan menempelkan lutut ke perut, hukuman dari ayah, menggantungkan tongkat, dan pukulan ringan.

\section{Pemberian Reward and Punishment Berdasarkan Pandangan Islam}


Segala sesuatu yang melanggar aturan tata tertib yang berlaku akan dikenai sanksi sesuai tingkat pelanggarannya. Tidak terkecuali dalam sebuah tata tertib pelaksanaan kegiatan belajar mengajar juga akan dilakukan hal yang sama ketika terjadi pelanggaran tata tertib oleh peserta didik. Begitu juga dalam Islam, segala perbuatan ada konsekuensinya. Jika melakukan perbuatan baik maka akan mendapatkan pahala, sedangkan jika melakukan perbuatan buruk akan mendapatkan dosa. Hal ini juga membuktikan bahwa reward and punishment mempunyai relevansi dengan pendidikan Islam melalui ayat-ayat Al-Qur'an maupun hadis-hadis Rasulullah.

Faktor bijak dalam pemberian reward dan punishment harus diperhatikan agar tidak salah kaprah, mengena, dan memiliki nilai positif terhadap respon anak. Akan lebih baik lagi penggunaan komunikasi yang lancar menjadi jembatan hubungan harmonis dan juga merupakan aspek yang penting di dalam proses pendidikan moral anak (Darma, 2001). Dengan begitu, ada kejelasan antara keinginan dan hal-hal yang berhubungan dengan anak dan orang tua sendiri. Orang tua merindukan anak memiliki nilai-nilai moral yang tinggi, di lain pihak anak memiliki keinginan dan kebutuhan semisal rasa kasih ingin dihargai dan kasih sayang.

Reward dapat memberikan pengaruh yang cukup besar terhadap jiwa anak didik untuk melakukan perbuatan yang positif dan bersikap progresif. Selain itu, reward juga dapat menjadi pendorong bagi anak-anak didik lainnya untuk mengikuti anak yang telah memperoleh pujian dari gurunya, baik dalam tingkah laku, sopan santun, ataupun semangat dan motivasinya dalam berbuat yang lebih baik. Proses ini sangat besar kontribusinya dalam memperlancar pencapaian tujuan pendidikan.

Dalam memberikan punishment kepada anak, orang tua dan pendidik (guru) dapat melakukan hal berikut ini:

1. Memberikan nasihat dengan cara dan pada waktu yang tepat

Maksudnya yaitu dengan tidak memojokkan dan mengungkit-ungkit kekeliruannya dengan nasihat yang panjang lebar, karena dapat membuat anak menolak terlebih dahulu apa yang akan disampaikan. Pemilihan waktupun harus dipertimbangkan sehingga anak bisa enjoy menerima masukan (Istadi, 2005). ada beberapa waktu yang tepat untuk menasihati anak (Rianti, 2013):

a. Saat rekreasi atau dalam perjalanan. Rasulullah suka menggunakan momen selama perjalanan dan rekreasi untuk menyampaikan pesanpesan penting dan berbobot. Orang tua dan pendidik dapat pula meniru metode ini, misalnya kegiatan belajar sambil rekreasi atau disebut rihlah. Disaat hati merasa senang, ruh dan pikiran dapat lebih mudah menyerap nasihat. 
b. Saat makan. Diriwayatkan dari Ibnu Umar bin Abu Salamah, ia berkata, "saat aku masih kecil, aku bermain di ruangan Rasulllah. Tanganku pun bertindak gegabah dalam aktivitas makanku. Rasulullah lalu bersabda kepadaku, 'wahai anak muda, sebutlah nama Allah, makan dengan tangan kananmu, dan makanan yang cocok denganmu.' Pada saat itu, cara makanku masih seperti dulu." (HR. Bukhari)

c. Sebelum anak tidur. Biasanya sebelum tidur suasana hati anak sedang dalam keadaan baik dan stabil. Sehingga apabila anak dinasihati maka dia akan merenspon dengan baik.

d. Ketika anak sedang tidur. Dengan cara membisikkan di telinga anak, orang tua dapat menyampaikan berulang-ulang perkataan atau nasihat yang akan terekam di alam bawah sadar anak.

e. Setelah anak bangun tidur. Misalnya, dengan memberikan kata-kata yang membangkitkan semangatnya.

f. Setelah anak mandi. Misalnya, dengan kata-kata lembut dan nasihat yang berkaitan dengan kebiasaan sehari-hari.

g. Setelah anak shalat. Misalnya, dengan kisah-kisah inspiratif yang memotivasi keimanan anak.

h. Setelah anak membaca Al-Qur'an. Misalnya, dengan menyampaikan kisah teladan dan urgensi ibadah.

i. Setelah anak berdoa. Misalnya, dengan menyampaikan pentingnya berdoa dan adab-adab berdoa.

j. Setelah anak melakukan perbuatan baik kepada orang lain. Hal ini akan menjadi penguatan agar anak semakin bersemangat berbuat baik kepada orang lain dan lingkungan.

k. Setelah anak meredam amarahnya. Orang tua dan pendidik dapat menasihati anak dengan lembut tapi tegas agar anak mengekspresikan emosi dengan cara yang baik.

2. Hukuman pengabaian, yaitu untuk menumbuhkan perasaan tidak nyaman dan teracuhkan di hati anak. Setelah tindakan pengabaian tak juga membawa hasil, barulah terakhir menginjak ke tahapan fisik.

3. Hukuman Fisik/Pukulan

Hukuman ini dijadikan sebagai tahap akhir dengan catatan bahwa hukuman fisik (pukulan) yang diberikan tidaklah terlalu keras dan menyakitkan. Hukuman fisik dalam pendidikan Islam merupakan keadaan darurat, bukan merupakan metode yang secara rutin harus diterapkan dalam proses kependidikan. Semestinya guru tidak usah menggunakan pukulan dalam mendidik anak-anak, kecuali kalau cara yang lunak tidak mendatangkan hasil yang diharapkan. Satu hal yang sangat baik adalah guru memperkecil penggunaan kekerasan atau tidak 
sama sekali. Athiyah Al-Abrasyi memberikan kriteria pemberian hukuman fisik yaitu (Al-Abrasyi, 1975):

a. Pemukulan tidak boleh dilakukan pada anak didik di bawah umur 10 tahun.

b. Alat pemukulnya bukan benda-benda yang membahayakan, misalnya lidi, tongkat kecil dan lain sebagainya.

c. Pukulan tidak boleh lebih dari tiga kali, dan

d. Hendaknya diberi kesempatan untuk tobat dari apa yang ia lakukan dan memperbaiki kesalahan yang pernah mereka kerjakan.

\section{KESIMPULAN}

Hasil penelitian membuktikan bahwa dalam dunia pendidikan reward diberikan ketika seorang anak telah berhasil mencapai sebuah tahap perkembangan tertentu, achievement yang bagus, atau tercapainya sebuah target. Sebaliknya, punishment biasanya dilakukan ketika apa yang menjadi target-target tertentu tidak tercapai, atau ada perilaku anak yang tidak sesuai dengan norma-norma yang diyakini oleh sekolah tersebut. Dalam Islam ada istilah basyir (berita gembira) dan nadzir (berita ancaman) yang dianalogikan dengan penghargaan dan hukuman. Rasulullah SAW sendiri adalah seorang pemberi berita gembira dan pemberi berita ancaman (basyira wa nadzira). Reward and punishment dalam pendidikan Islam tidak bisa dipisahkan dari konsep tujuan pendidikan Islam itu sendiri. Manusia yang bertakwa selalu menjadi salah satu kunci dalam rumusan tujuan pendidikan Islam, sehingga apabila anak didik menerima reward ataupun punishment, maka mereka diharapkan tidak hanya termotivasi secara umum saja, tetapi juga termotivasi secara rohani keagamaan untuk selalu berusaha menjadi manusia yang berakhlak baik seperti Rasulullah, dan termotivasi secara ketauhidan untuk selalu menjalankan hal positif dengan niat mencari keridhaan Allah SWT. Dan hukuman fisik dalam pendidikan Islam merupakan keadaan darurat, bukan merupakan metode yang secara rutin harus diterapkan dalam proses kependidikan. Semestinya guru tidak usah menggunakan pukulan dalam mendidik anak-anak, kecuali kalau cara yang lunak tidak mendatangkan hasil yang diharapkan.

\section{DAFTAR PUSTAKA}

Abu, Sunan Dawud. Nailul Authar juz 1, no. 495

Agus, Ayu Rianti. 2013. Cara Rasulullah SAW Mendidik Anak. Jakarta: Anggota IKAPI 
Ahmad, Al-Hafidz. 1998. Bin Ali, Fathul Baari, (HR. Bukhari no. 4771). Kairo: Darul Hadis. Hadist juz-8

Anshari, M. Hafi. 1993. Pengantar Ilmu Pendidikan. Surabaya: Usaha Nasional

Arif, Armai. 2002. Pengantar Ilmu dan Metodologi Pendidikan Islam. Jakarta: Ciputat Press

Arikunto, Suharsimi. 1990. Manajemen Pengajaran Secara Manusiawi. Jakarta: Rineka Cipta

Arifin, M. 2009. Ilmu Pendidikan Islam (Tinjauan Teoritis dan Praktis Berdasarkan Pendekatan Interdisiplener). Jakarta: PT Bumi Aksara

'Athiyyah, Moh. al-Abrasy. 1975. Tarbiyyah al Islamiyah wa Falsafatuha. Mesir: As-Syirkam

Bergner, Elizabeth Hurlock. 1990. Perkembangan anak, terj. Med. Meitasari Tjandrasa. Jakarta: Erlangga

Budaiwi, Ahmad Ali. 2002. Imbalan dan Hukuman Pengaruhnya bagi Pendidikan Anak. Jakarta : Gema Insani

Durkheim, Emile. 1990. Pendidikan Moral: Suatu Studi Teori dan Aplikasi Sosiologi Pendidikan, terj. Lukas Ginting. Jakarta: Erlangga

Fuad, Muhammad Abdi Al-Baqi. 1992. Al-Mu'jam Al-Mufahras li Al-Fadz AlQur'an. Beirut: Daar al-Fikr

Hadjar, Ibnu. 1999. Dasar-dasar Metodologi Penelitian Kualitatif dalam Pendidikan. Jakarta: RajaGrafindo Persada

H. Manser, Martin. 2003. Oxford learner's Pocket Dictionary. New York: Oxford University Press

Indrakusuma, A.D. 1973. Pengantar Ilmu Pengetahuan. Malang: Fakultas Ilmu Pendidikan IKIP Malang

Istadi, Irawati. 2005. Agar Hadiah dan Hukuman Efektif. Jakarta: Grafindo

Khalil, Najib Al-Amir. 1990. Tarbiyah Rasulullah, terj. Ibnu Muhammad \& Fakhruddin Nursyam. Jakarta: Gema Insani Press. cet. Ke-1

Khavari, Khalil A. 2006. The Art of Happiness (penerjemah: Agung Prihantoro), Jakarta: PT Serambi Ilmu Semesta 
Mas'ud, Abdurrahman. Reward and Punishment dalam Pendidikan Islam. Jurnal Media. Edisi 28, Th. IV, November

M. Echols, John, dan Hasan Sadily. 2003. Kamus Inggris-Indonesia Jakarta: PT. Gramedia

Mufidah, Durrotul, dkk. 2008. Sejarah Sosial Pendidikan Islam. Jakarta: Kencana

Mulyasa. 2007. Menjadi Guru Profesional Menciptakan Pembelajaran Kreatif dan Menyenangkan. Bandung: PT Remaja Rosda Karya

Munim, Abdul Ibrahim. Mendidik Anak Perempuan, terj. Abdul Hayyie alKattani dan Mujiburrahman Subadi

Nata, Abudin. 2000. Metodologi Studi Islam. Jakarta: Raja Grafindo Persada 2001. Pemikiran Para Tokoh Pendidikan Islam. Jakarta: Raja Grafindo

Nazir, Moh. 2003. Metode Penelitian. Jakarta: Ghalia Indonesia

Partanto, A. Pius dan M. Dahlan Al-Barry. 1994. Kamus Ilmiah Populer, Surabaya: Arkola

Purwanto, Ngalim. 1986. Ilmu Pendidikan Teoritis dan Praktis. Bandung: PT Remaja Rosda Karya

Raḩman, Abdul Shaleh. 2008. Psikologi: Suatu Pengantar dalam Perspektif Islam. Jakarta: Kencana

Said, Muhammad Mursi. 2004. Panduan Praktis dalam Pergaulan. Jakarta: Gema Insani. cet. ke-1

Santrock, John W. 2005. CHILDREN (Eight Edition). University of Texas: McGraw-Hill Companies

Satia, Monty P. Darma. 2001. Persepsi orang Tua Membentuk Perilaku Anak: Dampak Pygmalion di dalam Keluarga. Jakarta: Purtaka Populer Obor

Sax, Gilbert. Empirical Foundations Of Educational Research.New Jersey: Pentice Hall Inc, Engelewood Cliffs

Setiawani, Mary. 2000. Menembus Dunia Anak. Jakarta: Raja Grafindo Persada

Soehartono, Irawan. 2002. Metode Penelitian Sosial. Bandung: Remaja Rosdakarya 
Sugiyono. 2009. Metode Penelitian Kuantitatif Kualitatif dan $R \& D$, Bandung: Alfabeta

Suryabrata, Sumardi. 1989. Metodologi Penelitian. Jakarta: Rajawali Press

Usman, Muhammad Najati. 2005. Psikologi dalam Al-Qur'an, terj. M. Zaka AlFarisi. Bandung: Pustaka Setia. cet. ke-1 